\title{
A rapid protocol for purification of total RNA for tissues collected from pigs at a slaughterhouse
}

\author{
V. Méndez, E. Avelar, A. Morales, M. Cervantes, A. Araiza and D. González \\ Instituto de Ciencias Agrícolas, Universidad Autónoma de Baja California, \\ Mexicali, México \\ Corresponding author: A. Morales \\ E-mail: adriana_morales@uabc.edu.mx
}

Genet. Mol. Res. 10 (4): 3251-3255 (2011)

Received January 26, 2011

Accepted June 24, 2011

Published December 22, 2011

DOI http://dx.doi.org/10.4238/2011.December.22.3

\begin{abstract}
Since RNA extraction is a crucial step in many molecular techniques, the protocols for sample collection and RNA purification need to be adapted to optimize their performance when samples are collected from animals at commercial facilities. Here we provide an RNA purification protocol for animal tissues collected from slaughterhouses. This protocol, modified from other techniques, uses TRIzol Reagent. Sample collection was performed wearing sterile gloves and facemasks, using sterile surgical instruments, and no longer than $8 \mathrm{~min}$ spent for each sample. A $0.9 \%$ sterile sodium chloride solution was used to wash the tissue before each sample collection. The whole process of RNA extraction was performed under cold environment and sterile conditions. This protocol produced good RNA yields (50 $\mu \mathrm{g}$ RNA per $100 \mathrm{mg}$ tissue), good integrity and purity $\left(\mathrm{Abs}_{260 / 280}\right.$ from 1.8 to 2.0), from tissues such as liver, muscle, hypophysis, adipose tissue, and intestinal mucosa, in less than $2 \mathrm{~h}$.
\end{abstract}

Key words: RNA purification; Pigs; Slaughterhouse 


\section{INTRODUCTION}

Animal science reports from recent years show a marked tendency to explain metabolic and pathologic process using complex protocols of molecular biology. Regularly, these protocols include the use of laboratory animals (e.g., mice and rats) housed and processed under strict and controlled laboratory conditions. However, some studies require the use of tissues collected from animals sacrificed at facilities other than laboratories, such as slaughterhouses. Regardless of where tissue samples are collected, the isolated RNA has to be of good quality to be used in molecular biology protocols.

There is a significant risk of isolated RNA losing quality because of the nuclease activity and the presence of contaminating agents (blood, water and manure), sampling time, ambient temperature, and the time span between sacrificing the animal and sample collection (Holland et al., 2003). Since RNA is a crucial step in many molecular techniques, the protocols for sample collection and RNA purification need to be adapted to optimize their performance when samples are collected from animals at commercial facilities. The time spent between the slaughter and sampling, ambient temperature, and endogenous nucleases from tissues or environment are the main factors that need to be avoided during tissue sampling and processing.

Thus, the aim of this study was to standardize a protocol for RNA purification from a variety of tissues collected at a slaughterhouse and to optimize RNA integrity, which could be used for molecular analysis.

\section{MATERIAL AND METHODS}

This study was carried out at the Instituto de Ciencias Agrícolas of Universidad Autónoma de Baja California, Mexico. Some protocols for purifying RNA from different authors (Chomczynski and Sacchi, 1987; Zolfaghari et al., 1993; Sambrook and Russell, 2001; TRIzol Reagent protocol, Invitrogen, 2007) were used and modified to obtain the best RNA quality.

\section{Sample collection}

Thirty-six pigs at different ages that were sacrificed for commercial and research purposes were sampled at the slaughterhouse of this institute. Tissue samples with different properties and characteristics were collected from liver, muscles (semitendinosus and longissimus dorsi), hypophysis, adipose tissue, and intestinal mucosa (duodenum, jejunum and ileum). Animals were sacrificed by exsanguination after electro shock stunning, followed by offal removal and carcass processing. To avoid contamination and minimize nuclease activity the total sampling time, defined as the time spent from the very moment the animal was electrically stunned until the tissue sample was placed in liquid nitrogen, took no longer than $8 \mathrm{~min}$. The personnel responsible for tissue sample collection wore sterile gloves and facemasks, and used sterile surgical instruments (scalpels, forceps, scissors, and glass slides) during the sampling procedure. Also, $0.9 \%$ sterile sodium chloride solution was used to wash the tissue samples.

Tissue sample collection was performed as follows. For compact organs such as liver, muscle and adipose tissue, samples of 0.3-0.5 g were collected from the inside of the organ or tissue using scissors and forceps. Hypophysis was totally removed after craniotomy was 
performed with the help of a sterile saw, forceps and scissors. Intestinal mucosa was scraped with a glass slide after the surface of small portions of the intestine was washed with saline solution. All samples were placed into $2.0-\mathrm{mL}$ cry tubes previously identified and immediately frozen in liquid nitrogen. Then, all samples were stored at $-80^{\circ} \mathrm{C}$ until they were analyzed.

\section{RNA extraction procedure}

Mortar and pestle, previously sterilized, were used to pulverize about $0.3 \mathrm{mg}$ of each sample in liquid nitrogen; samples were crushed until a fine powder was obtained. Approximately 50 to $100 \mathrm{mg}$ powder was recovered from each sample and placed into a new cold 2-mL microtube, previously identified; then, $1000 \mu \mathrm{L}$ TRIzol (Invitrogen, USA) was added and mixed by inverting the tube to help cell lysis from tissue samples. The TRIzol solution containing the disrupted tissue was then centrifuged at $12,000 \mathrm{~g}$ for $10 \mathrm{~min}$ at $4^{\circ} \mathrm{C}$. The colorless supernatant phase was collected into a new $2-\mathrm{mL}$ tube and incubated in ice for $5 \mathrm{~min}$; then, $200 \mu \mathrm{L}$ chloroform (Sigma-Aldrich) were added to the reaction, vigorously hand shaken, and incubated in ice for 2 more minutes. This solution was centrifuged at $12,000 \mathrm{~g}$ for $15 \mathrm{~min}$ at $4^{\circ} \mathrm{C}$, and the aqueous phase was collected into a new cold tube.

\section{RNA precipitation}

Cold isopropyl alcohol (500 $\mu \mathrm{L}$; Sigma-Aldrich) was added to the solution from RNA separation, shaken by inverting the tube and incubated in ice for $10 \mathrm{~min}$. The solution was centrifuged at $12,000 \mathrm{~g}$ for $10 \mathrm{~min}$ at $4^{\circ} \mathrm{C}$. Supernatant was decanted and the pellet recovered.

\section{RNA wash and suspension}

The RNA pellet was washed with $1000 \mu \mathrm{L}$ cold $100 \%$ ethanol (Sigma-Aldrich) and the tube was inverted to softly wash the RNA. The solution was centrifuged at $9000 \mathrm{~g}$ for $5 \mathrm{~min}$ at $4^{\circ} \mathrm{C}$. The supernatant was decanted, and the pellet recovered and air-dried at room temperature for about 10 to $15 \mathrm{~min}$. RNA was dissolved into 30 to $50 \mu \mathrm{L}$ DEPC-treated water by pipetting the solution a few times. The quality of RNA was evaluated on $1 \%$ agarose gel electrophoresis and quantified spectrophotometrically at an absorbance of $260 \mathrm{~nm}$, and purity estimated by absorbance ratio at 260/280.

\section{RT-PCR}

To demonstrate whether RNA samples were good enough to use in molecular techniques, RT-PCR analysis was performed. Approximately $2 \mu \mathrm{g}$ total RNA was treated with $1 \mathrm{U}$ DNase I enzyme (Invitrogen) and retrotranscription was performed with random primers (Invitrogen) and RT-Supersacript III reverse transcriptase enzyme (Invitrogen). For all the pig samples, the 18SRibosomal RNA(GenBank No. AY265350) was amplified using specific oligonucleotides (sense: 5'-GGCCTCACTAAACCATCCAA-3'; antisense: 5'-TAGAGGGACAAGTGGCGTTC-3') to obtain a 295-bp product, using Taq DNA recombinant polymerase (Invitrogen). The program for PCR amplification started with DNA denaturing for 2 min at $94^{\circ} \mathrm{C}$, followed by 35 cycles of denaturing $\left(30 \mathrm{~s}\right.$ each at $\left.94^{\circ} \mathrm{C}\right)$, annealing $\left(1 \mathrm{~min}\right.$ each at $\left.58^{\circ} \mathrm{C}\right)$, elongation $\left(30 \mathrm{~s}\right.$ each at $\left.72^{\circ} \mathrm{C}\right)$, 
and a final extension $\left(2 \mathrm{~min}\right.$ each at $\left.72^{\circ} \mathrm{C}\right)$. PCR products were analyzed on agarose gel electrophoresis and by melting curve analysis using real-time PCR.

\section{RESULTS AND DISCUSSION}

The yield of RNA in all extracted samples was above $50 \mu \mathrm{g} / 100 \mathrm{mg}$ tissue. Absorbance ratios $(260 / 280 \mathrm{~nm})$ ranged from 1.8 to 2.0 in all RNA samples, which indicate no significant protein contamination. Agarose gel electrophoresis stained with ethidium bromide showed good integrity of the purified RNA (Figure 1). Total time for purification was less than $2 \mathrm{~h}$. To test the quality of the purified RNA, RT-PCR assays were performed to amplify a 295-bp cDNA product of 18S-Ribosomal RNA in all the samples; some of these products are shown in Figure 2.


Figure 1. Agarose gel electrophoresis of purified RNA from pig tissue samples. A. Duodenal mucosae; B. jejunal mucosae; C. adipose tissue; D. liver; E. hypophysis; F. longissimus dorsi muscle; G. semitendinosus muscle.

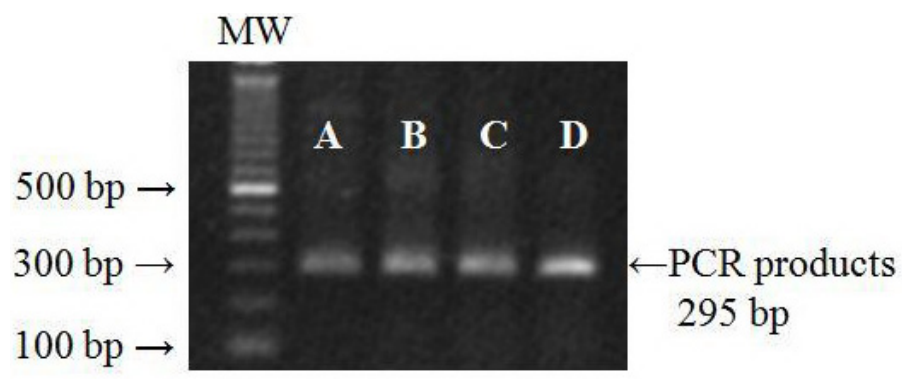

Figure 2. Agarose gel electrophoresis of a 295-bp cDNA product of 18S-Ribosomal RNA amplified from RNA purified from: lane $A=$ jejunum; lane $B=$ adipose tissue; lane $C=$ liver; lane $D=$ hypophysis. $\mathrm{MW}=$ molecular weight marker.

To standardize this protocol, studies for RNA purification from different authors (Chomczynski and Sacchi, 1987; Sambrook and Russell, 2001; Zolfaghari et al., 1993; TRIzol Reagent protocol, Invitrogen) were searched and modified to get the best RNA quality, which was increased with some modifications. Because of its efficiency and easy protocol, TRIzol Reagent was the product selected.

The first steps between sampling and processing the tissues seem to be the crucial part for obtaining good-quality RNA. The time spent for sample collection, right after the animal is 
stunned, has to be short because the manipulation that occurs during carcass processing and the microorganisms present around the slaughterhouse environment may produce some contamination.

Different size of samples were probed, from 0.1 to $2.0 \mathrm{~g}$, and the best result was with small amounts of tissue samples because they are easy to freeze and to maintain frozen during its pulverization; this helps to prevent the activation of nucleases that could be attached to the nucleic acids (Chomczynski and Sacchi, 2006). For this step, we found that tissue homogenization with the use of an electrical homogenizer can increase the tissue temperature and some RNA could be degraded by the end of the purification process.

Temperatures used in RNA purification were also probed and best results were obtained when almost all steps after the lysis process occurred at refrigeration $\left(2-6^{\circ} \mathrm{C}\right)$ temperature. During the washing step, the use of 90 or $100 \%$ ethanol is recommended just once. The RNA is preferably recovered in DEPC-treated water instead of TE buffer, or formamide or other solutions, to avoid interference with future enzymatic reactions (Arezi et al., 2010). To avoid contamination, it is also recommended that sterile saline solution be used for washing the tissues before sampling, and that samples be taken from the interior of parenchymal organs. With this protocol we were able to isolate good-quality RNA from different kinds of tissues including adipose tissue, even when its cells are bigger, and contain large amounts of fat. Additionally, this protocol provides a rapid, reliable and low-cost alternative for RNA purification from a variety of animal tissues collected at a slaughterhouse that can be used for molecular analysis in animal science research.

\section{ACKNOWLEDGMENTS}

Research supported by a grant (\#00061299) from the Consejo Nacional de Ciencia y Tecnología (CONACYT)-Mexico.

\section{REFERENCES}

Arezi B, McCarthy M and Hogrefe H (2010). Mutant of Moloney murine leukemia virus reverse transcriptase exhibits higher resistance to common RT-qPCR inhibitors. Anal. Biochem. 400: 301-303.

Chomczynski P and Sacchi N (1987). Single-step method of RNA isolation by acid guanidinium thiocyanate-phenolchloroform extraction. Anal. Biochem. 162: 156-159.

Chomczynski P and Sacchi N (2006). The single-step method of RNA isolation by acid guanidinium thiocyanate-phenolchloroform extraction: twenty-something years on. Nat. Protoc. 1: 581-585.

Holland NT, Smith MT, Eskenazi B and Bastaki M (2003). Biological sample collection and processing for molecular epidemiological studies. Mutat. Res. 543: 217-234.

Sambrook J and Russell DW (2001). Molecular Cloning: A Laboratory Manual. 3rd edn. Cold Spring Harbor Laboratory Press, New York.

Zolfaghari R, Chen X and Fisher EA (1993). Simple method for extracting RNA from cultured cells and tissue with guanidine salts. Clin. Chem. 39: 1408-1411. 